\title{
MENINGORADICULITIS DUE TO CRYPTOCOCCUS NEOFORMANS IN AN IMMUNOCOMPETENT PATIENT
}

\author{
Leonardo Deus-Silva', Alexandre E. Costa', Juliano M. Bevilacqua², \\ Denise B. Assis', Carlos A. Ferraz Jr. ${ }^{2}$, Augusto C.P. Oliveira ${ }^{3}$, Anamarli Nucci ${ }^{4}$
}

\begin{abstract}
Meningoradiculitis refers to combined involvement of meninges and nerve roots. The most frequent location is the lumbosacral region. Etiology is diverse, including inflammatory, infectious and neoplastic disorders. Meningoradiculitis is a rare form of involvement in cryptococcal infection. We describe a case of subacute lower limbs flaccid paresis diagnosed as lumbosacral meningoradiculitis in view of cerebrospinal fluid (CSF) inflammatory changes and typical enhancement on MRI of lumbar spine. Cryptococcus neoformans was isolated from CSF. Extensive screening yielded no immunodeficiencies.
\end{abstract}

KEY WORDS: Cryptococcus neoformans, meningoradiculitis, immunocompetent.

\begin{abstract}
Meningorradiculite lombossacra causada por Cryptococcus neoformans em paciente imunocompetente

RESUMO - Meningorradiculite refere-se ao envolvimento simultâneo das meninges e das raízes dos nervos. O local mais freqüentemente acometido é a região lombossacra. Patologias inflamatórias, infecciosas e neoplásicas são as causas mais freqüentes. Meningorradiculite é manifestação rara de infecção por Cryptococcus neoformans. Descrevemos um caso de paresia flácida dos membros inferiores, com diagnóstico de meningorradiculite lombossacra baseado nos achados clínicos, de ressonância magnética da coluna lombar e em alterações inflamatórias do líquido cefalorraqueano (LCR). Avaliação microbiológica do LCR revelou a presença de Cryptococcus neoformans e extensa investigação clínica e laboratorial excluiu imunodeficiências primárias e adquiridas.
\end{abstract}

PALAVRAS-CHAVE: Cryptococcus neoformans, meningorradiculite, imunocompetente.

Meningoradiculitis refers to combined and exclusive involvement of meninges and nerve roots. The most frequent location is the lumbosacral region. Etiology is diverse, including inflammatory, infectious and neoplastic disorders. Our aim is to describe and discuss a case of lumbosacral meningoradiculitis caused by Cryptococcus neoformans in an immunocompetent patient.

\section{CASE}

A 14 year-old female was admitted due to progressive difficult walking that had started three months earlier. She was already being investigated for chronic daily fever that had begun ten months before. Fever was more common on late afternoon and reached $39^{\circ} \mathrm{C}$. She also presented malaise, headache and an estimated weight loss of $15 \mathrm{Kg}$ during this period. Seven months after the beginning of the fever, the patient started to present gait difficulty, which was initially characterized by weakness of the right lower limb associated to lumbar pain that radiated to posterior thigh. This weakness evolved to the point that she could barely walk. She denied sensory and sphincter disturbances. Her past medical history was unremarkable but her father had been treated for tuberculosis. General physical examination was normal and neurological examination disclosed an asymmetric flaccid paresis of the lower limbs, worse on the right side, corresponding to roots L2 to S1. Muscle stretch reflexes were normal in upper limbs, knee jerk was absent and ankle jerk was hypoactive bilaterally. Plantar reflexes were both normal. All kinds of sensation, coordination and cranial nerves were intact. Lasègue sign was present bilaterally.

Lumbar puncture yielded in the cerebrospinal fluid (CSF) sample: 496 cells $/ \mathrm{mm}^{3}$ (neutrophils $57 \%$; lymphocytes $41 \%$; monocytes $2 \%$ ), total protein $286 \mathrm{mg} / \mathrm{dL}$ and glucose $06 \mathrm{mg} / \mathrm{dL}$. India-ink preparation of CSF revealed

Medical Sciences School (FCM) of the Campinas State University (UNICAMP), Campinas SP, Brazil: Resident ${ }^{1}$ and Assistant Professor ${ }^{4}$, Department of Neurology; Resident ${ }^{2}$ and Assistant Physician'3 ${ }^{3}$ Department of Infectious Diseases.

Received 11 June 2003, received in final form 20 August 2003. Accepted 18 September 2003.

Dr. Leonardo Deus-Silva - Departamento de Neurologia - FCMIUNICAMP - Caixa Postal: 6111 - 13083-970 Campinas SP Brasil. E-mail: dedeus@unicamp.br 


\author{
Fig 1. Sagittal plane \\ T1-weighted MRI of \\ lumbosacral spine \\ after injection of \\ gadolinium showing \\ leptomeningeal \\ enhancement
}

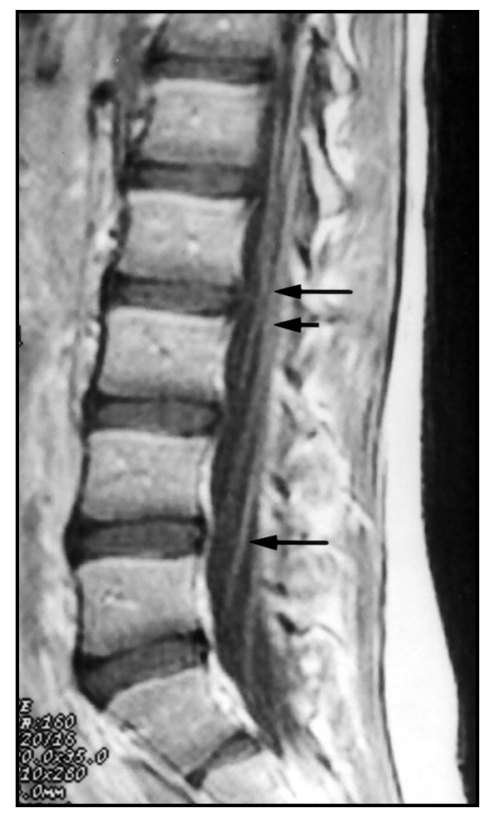

Fig 2. Sagittal plane T1-weighted MRI of lumbosacral spine after injection of gadolinium showing enhancement of cauda equina nerve roots encapsulated yeast-like fungi. The Cryptococcus neoformans antigen latex agglutination test was positive and Cryptococcus neoformans var. gattii was isolated from the CSF. Electroneurography disclosed normal motor and sensory conduction velocities and a prolonged $\mathrm{F}$ reponse of the right tibial nerve. The patient refused to be submitted to EMG. Magnetic resonance imaging (MRI) of lumbar and sacral spine showed meningeal thickening and enhancement of lumbar and sacral roots by gadolinium (Figs 1-3). Brain MRI was normal. Therapy with amphotericin - B was started with good clinical and laboratory improvement. A thorough screening excluded immunodeficiencies and there was no involvement of other organs by the cryptococcal infection.

\section{DISCUSSION}

Cryptococcus neoformans is a yeast-like fungus classified into two varieties based on the serologic characteristics of the polysaccharide capsule and mating properties of the sexual stage 1 . C. neoformans var. neoformans is found worldwide in many environments, including contaminated soil. Pigeon's feces are believed to be an important source of contamination. C. neoformans var. gatti is limited to eucalyptus trees found in Australia, Southeast Asia, Central Africa, and southern California ${ }^{2}$. C. neoformans var. neoformans are most frequently found in immunosupressed patients whereas $C$. neoformans var. gatti are encountered in immunocompetent patients. Neurological involvement in Cryptococcus neoformans infection is quite common in immunodeficient patients, especially the HIV-infected patient. Approximately $50 \%$ of non-AIDS patients have pre-existing diseases. Lymphoma, dia- betes mellitus, and chronic steroid therapy are the most commonly associated conditions. The remaining patients have no known underlying disease ${ }^{3}$. Cryptococcal infection occurs in $6 \%$ to $10 \%$ of HIVinfected patients at some time during their illness. The most common form of involvement is meningitis and occurs in $66 \%$ to $84 \%$ of these patients ${ }^{4,5}$. It is the most frequent cause of secondary headache in AIDS patients.

Infection results from inhalation of $C$. neoformans, which is usually limited to the lung. The meninges are the preferred site of cryptococcal infection following dissemination of the organism. This predilection for meningeal infection is attributed

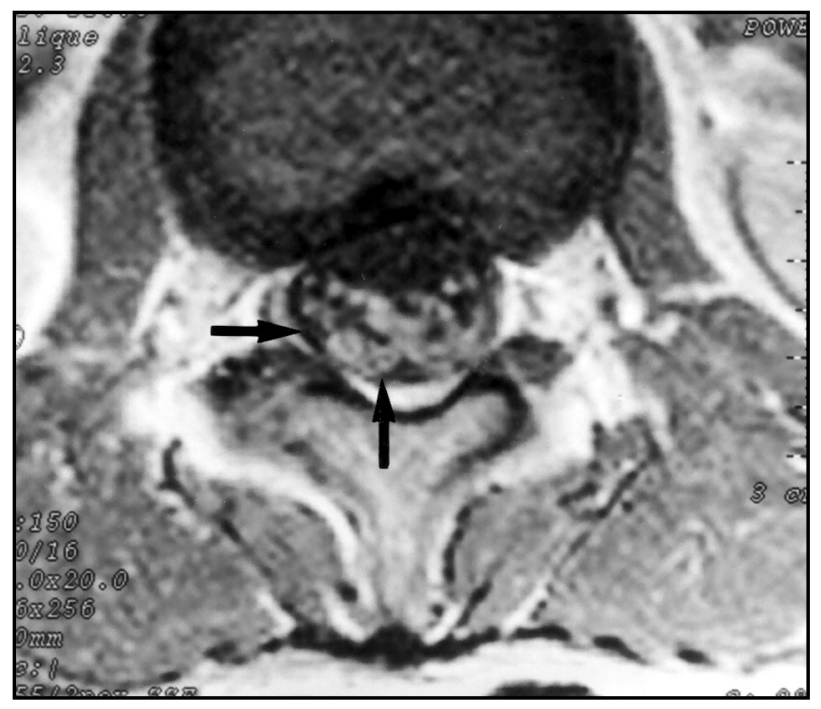

Fig 3. Axial plane T1-weighted MRI of cauda equina after injection of gadolinium showing massive nerve root enhancement. 
to several factors, including a negligible inflammatory response in the CSF, limited chemotaxis by the lack of the alternate pathway of complement in CSF and the poor chemotactic properties of the polysaccharide capsule. CSF is an excellent growth medium for $C$. neoformans. Anticryptococcal protein factors present in serum are not found in $\mathrm{CSF}^{6}$.

CSF examination is an important tool in defining the etiology of any infection with involvement of the nervous system. CSF of our patient had two relevant findings that could misguide the etiologic diagnosis. We found a slightly predominant neutrophilic pleocytosis and a very low level of glucose, both findings suggestive of bacterial infection. Isolation of the fungi from the CSF was diagnostic and, therefore, these unusual findings in the CSF of our patient are likely to be explained by a stronger immunological response. This consideration is based on the difference in CSF findings of AIDS and non-AIDS patients with cryptococcosis. In the former, the CSF may show minimal changes. A lymphocytic pleocytosis is usually present in $60 \%$ of patients and cell count will disclose less than $20 \mathrm{cells} / \mathrm{mm}^{3}$. CSF glucose is usually normal and protein concentrations may vary from normal to $300 \mathrm{mg} / \mathrm{dL}$. Yeasts are identified in India ink preparations in $75 \%$ of cases and CSF cryptococcal antigen titers are positive in $90 \%$ to $100 \%$ of patients. Serum cryptococcal antigen titers are positive in up to $99 \%$ of cas$\mathrm{es}^{7}$. A positive cryptococcal antigen test is sufficient evidence of cryptococcal infection to initiate therapy until cryptococcal culture results are available.

In non-AIDS patients, CSF is more reactive than that seen in AIDS-related cryptococcal meningitis ${ }^{8}$. A lymphocytic pleocytosis with cell counts up to 800 cells $/ \mathrm{mm}^{3}$ is common. Hypoglycorrhachia is practically always found with glucose concentrations as low as 10 to $20 \mathrm{mg} / \mathrm{dL}$ in some patients. CSF protein is elevated in most non-AIDS patients (range 45 to $600 \mathrm{mg} / \mathrm{dL}$ ). Yeasts are seen by India ink examination in $50 \%$ of non-AIDS patients with cryptococcal meningitis. CSF cryptococcal antigen titers are positive in $90 \%$ of non-AIDS patients, but serum cryptococcal antigen is detected in only $50 \%$ of cases. Cryptococcal cultures of CSF may be negative in up to $25 \%$ of cases. Repeated examination of large volumes of CSF by India ink and fungal culture may be required to confirm the diagnosis in some patients.

Meningoradiculitis is a rare form of involvement in cryptococcal infection ${ }^{9}$. Involvement of spine has been reviewed and 11 documented cases were found up to 1989, in the form of cryptococcal spondylitis ${ }^{10,11}$. The findings were indistinguishable from tuberculous spondylitis, with involvement of the vertebral body and extensive involvement of the posterior elements and paraspinous and perivertebral soft tissues with relative preservation of the disc, which was not the case of our patient. Flaccid weakness, that in part resembles GuillainBarré syndrome, is more often found in Lyme disease, syphilis, tuberculosis and brucellosis. Herpes simplex and CMV infections are important causes in the immunosupressed patient. Our patient was submitted to an extensive screening, which did not yield any immunodeficiency. Other non-infectious inflammatory diseases such as sarcoidosis were also excluded. The neuroimaging findings are remarkable, although not specific. Contrast enhancement is attributed to active inflammatory process and can be a guiding tool in the assessment of treatment efficacy. Post-treatment MRI of our patient showed lack of enhancement, confirming the resolution of the infection.

In conclusion, we suggest that cryptococcal infection should be included in the differential diagnosis of subacute and chronic flaccid paralysis, especially if there is involvement of lumbosacral roots and CSF points to an infectious disease. Although presenting as an alarming neurological condition at first, cryptococcal meningoradiculitis is a treatable disease and specific treatment avoids permanent disability

\section{REFERENCES}

1. Diamond RD. Cryptococcus neoformans. In Mandell GL, (ed). Principles and practice of infectious diseases. Philadelphia: Churchill Livingstone, 2000:2707-2716

2. Ellis DH, Pfeiffer TJ. Natural habitat of Cryptococcus neoformans var. gatti. J Clin Microbiol 1990;28:1642-1644.

3. Weenink HR, Bruyn GW. Cryptococcosis of the nervous system. In Vinken P, Bruyn G J (ed). Handbook of clinical neurology Infections of the nervous system part III. Amsterdam: North Holland, 1978:459-502.

4. Panther LA, Sande MA. Cryptococcal meningitis in the acquired immunodeficiency syndrome. Semin Respir Infect 1990;5:138-145.

5. Masci JR, Poon M, Wormser GP, Bottone EJ. Cryptococcus neoformans infections in the era of AIDS. In Wormser GP (ed). AIDS and other manifestations of HIV infection. New York: Raven Press, 1992:393-408.

6. Diamond R, Root RK, Bennett JE. Factors influencing killing of Cryptococcus neoformans by human leukocytes in vitro. J Infect Dis 1972;125:367-376.

7. Kovacs JA, Kovacs AA, Polis M, et al. Cryptococcosis in the acquired immunodeficiency syndrome. Ann Intern Med 1985;103:533-558.

8. Livramento JA, Machado LR, Nobrega JP, Gomes HR, Vianna LS, SpinaFrança A. CSF in 85 patients with AIDS and CNS cryptococcosis. Arq Neuropsiquiatr 1992;50:491-496.

9. Dichgans M, Seelos K, Wick M, Pfister HW. Meningoradiculitis with severe tetraparesis, an unusual manifestation of infection due to Cryptococcus neoformans var. gattii. Clin Infect Dis 1998;26:524-525.

10. Lie KW, Yu YL, Cheng IK, Woo E, Wong WT. Cryptococcal infection of the lumbar spine. J R Soc Med 1989;82:172-173.

11. Cure JK, Mirich DR. MR imaging in cryptococcal spondylitis. AJNR Am J Neuroradiol 1991;12:1111-1112. 